\title{
CORRIGENDUM
}

\section{Protein kinase WNK2 inhibits cell proliferation by negatively modulating the activation of MEK1/ERK1/2}

S Moniz, F Veríssimo, P Matos, R Brazão, E Silva, L Kotelevets, E Chastre, C Gespach and P Jordan

Oncogene (2008) 27, 155; doi:10.1038/sj.onc.1210931

\section{Correction to:}

Oncogene (2007) 26, 6071-6081; doi:10.1038/ sj.onc.1210706; published online 30 July 2007.
Since the publication of the above manuscript, the authors have identified an error in the author list; the name of the sixth author was misspelt. The corrected author list is shown above. 